A large number of bacteria possess this power of producing rennet, though not more than nine or ten have thus far been experimented upon. Those studied differ much in the amount of the ferment produced, some giving large quantities, and others only traces. Thus far it seems that all species of bacteria which liquefy gelatin produce this reinnet ferment, although some of them only in small amount.

This general line of work is thus leading bacteriologists to a better understanding of the fermentations, although we are as yet doubtless far from any real knowledge of their nature.

\section{IS THE SÂO FRANCISCO DO SUL (SANTA CATHARINA)} IRON A METEORITE?

by oRVille a. Derby, sâo paulo, Brazil.

THE possibility of a terrestrial origin for masses of native iron being established by the well-known occurrence at Ovifak, Greenland, doubt may be cast on the mode of origin of such so-called meteorites as in their chemical and physical characters depart widely from the ordinary type of meteoric iron. From its size and prominence in meteoric literature the most important example of such a doubtful iron is that found in 1875 near the city of Sâo Francisco do Sul, in the State of Santa Catharina, Brazil, and generally known as the Santa Catharina iron or me teorite. Professors Daubree and Stanislas Meunier regard it as undoubtedly meteoric; while Dr. A. Brezina, whose opinion is equally entitled to respect, considers it as probably terrestrial, placing it alongside of the Ovifak iron in his catalogue of the Vienna collection.

So far as known to the writer, no such minute study as Brezina, Cohen, and others have given to various undoubted meteorites has as yet been made of the Ovifak iron, so that at present we are in the dark as to whether or not it presents definite criteria by which a terrestrial iron can be positively separated from a meteoric one. So many of the characteristics once presumed to be purely meteoric have already been noticed, either in the Ovifak or artificial irons, that it may be doubted if any such definite criteria exist. The published analyses of Ovifak show that neither the nickel-iron alloys nor the association with a monosulphide (troilite) carbon free or combined and phosphorus can be taken as distinctive of meteorites. It is not clear, however, if the carbon presents the same form as in meteorites, that is to say, free in the form of amorphous carbon, graphite, cliftonite, diamond (?), etc., and combined as cohenite, nor if the phosphorus is combined with iron and nickel as in the meteoric minerals schreibersite and rhabdite. On the other hand, the compact (Dichte Eisen) group of Brezina containing at least nine undoubted meteorites, one of which, Nedagolla, was seen to fall, proves that the absence of a certain crystalline structure, indicated by the socalled Widmanstätten and Neumann figures, is not necessarily proof of non-meteoric origin. On the contrary, evidence is accumulating that a very similar if not absolutely identical crystalline structure may, under favorable circumstances, appear in artificial irons. Huntington has illustrated figures very like those of Widmanstätten in spiegel-eisen; Linck has described a crystal from a furnace slag, with cube faces and a polysynthetic twinning structure, which he identifies with the Neumann figures, and a perfect octahedral crystal with a similar twinning structure has recently come into the possession of the writer from a Brazilian blast-furnace.

It may be presumed that it is mainly on the absence of the characteristic meteoric figures that Brezina depends in placing the Sâo Francisco do Sul with the Ovifak iron, as in no other respect are they markedly similar. The Brazilian iron does, however, show, at least in places, a very fine rectilinear cross-hatching indicative of polsynthetic twinning, but according to some law different from that giving the Neumann lines. Another point of agreement is in the abundant occurrence of the magnetic oxide of iron which is either absent from most meteorites or has been overlooked in their description. Both irons are brittle, being readily broken to fragments with a hammer, in which re- spect they differ from the tenaceous malleable metal of most meteorites. Both also crumble to fragments in the atmosphere of museums, though apparently not from the same cause, the crumbling of Sâo Francisco do Sul being due to alteration of the sulphide, which presumably is not the case with Ovifak.

Lawrence Smith and Becherel found the magnetism of the Brazilian metal abnormally weak but that it became normal on heating, from which they concluded that the mass could not have been subjected to great heat. There seems, however, to be a variation in this respect in different parts, since Daubree notes that many fragments exhibit polar magnetism while others do not. Any argument drawn from the magnetic properties would apparently tell as much against a terrestrial as a cosmic origin, since the only conceivable mode of terrestrial origin is in the midst of an igneous magma made fluid by heat.

In other respects, however, a parallel for the characteristic features of the Sâo Francisco do Sul iron is to be looked for in the group of meteoric irons rather than in those, so far as published, of the terrestrial iron of Orifak. It is particularly characterized by the high percentage of nickel and the extraordinary abundance of sulphide. In the first respect its nearest ally is the Oktibbeha meteorite with nearly double the proportion of nickel, and not the Ovifak iron in which that metal is below the meteoric average. Unlike any other known iron, meteoric or terrestrial, the sulphide forms a gangue inclosing the metallic parts, but it is interesting to notice that it also presents itself in pencil-like inclusions in the metal, surrounded by carbon and other accessories, as in the Bendegó meteorite. The meteoric phosphurets, schreibersite and rhabdite, not yet described from, though perhaps present in, the Ovifak iron, are abundant accessories. In the carbonaceous residue, soft, friable granules, with a crystalline form suggestive of the cliftonite of the Youngedin, Magura, and Bendegó meteorites, have been noticed.

Thus, so far as at present known, the chemical and physical characteristics of the Sâo Francisco do Sul iron do not point very markedly to an association with that of Ovifak. What is known of the geological conditions of the place of discovery, although too incomplete to be decisive, points rather to a meteoric origin.

The geological information regarding the place of discovery is derived from verbal communications by the late Professor Ch. Fred. Hartt, a paper in the Revista do Observatorio de Rio de Janeiro for 1888 by Dr. Luiz F. Gonzaga de Campos, and a recent article in the Jornal do Commercio of Rio, May 29, 1892, by Dr. J. P. Calogeras. All these accounts agree in representing the island of Sâo Francisco do Sul as composed essentially of granitoid gneiss cut by dykes of tourmaline granite and diabase and covered by a heavily-wooded soil-cap due to the decay of the underlying rocks. That is to say, it is a typical locality of the coast-belt from Cape Frio to Montevideo, at any point of which, so far as geological indications go, native iron might be looked for with as great probability as at this particular locality. The rocks, granite, gneiss, and diabase, are well exposed about the shores of the island. The latter, which approaches most nearly in character the Ovifak rock, being apparently no more abundant than in any other similar locality. In the interior of the island the soil-cap and forest growth make geological observations difficult. Dr. Campos, in his examination of the place of discovery of the iron, opened numerous paths and pits, and on my recommendation paid particular attention to the question of the possible occurrence of basic rocks in immediate connection with the iron. He says, "Although the rock on this hillside is much altered, giving an argillaceous soil of a red color, here more, there less deep in tint, it shows perfectly in some points the mineral composition of granite. At the top of the hill near the point $c$ [one of the points where masses of iron were found] there are large blocks of granite, at times tourmaliniferous. In the vicinity, in all the directions that I followed, all the soil is granitic. In the bed of the stream, which I ascended in various sections, the material was always that of the disaggregation of granitoid gneiss. Finally, I did not find at this place a single exposure of basic rock." The numerous specimens that have come to hand showing foreign material cemented to the iron by the limonite crust formed by its alteration are in accord with this description, indi- 
cating, as Daubree has always remarked, that the iron rested on a granitic soil.

The topographical sketch of the locality made by Dr. Campos shows no indication of concealed dykes of basic rocks, which, according to universal experience of occurrences under similar conditions in Brazil, should, from their more ready decomposition, form depressions on the surface. The principal mass was found at the foot of the hill near a creek on the point of a spur, and aligned with a mass about 200 meters distant at the extreme summit of the hill and with an intermediate find close to an exposure of granite on the same spur. The other finds are aligned parallel to the course of the creek. In one pit on this line iron was found to a depth of 2.8 meters, covered with wash earth brought down by the rain from the higher portions of the hill.

Dr. Calogeras, who argues in favor of a terrestrial origin, presents no facts in disaccord with the above observation that the only rock known in the immediate vicinity of the iron is granitic. His argument, based on the occurrence in the region (principally at a distance of several miles) of iron and manganese ores (oxides), and presumed to be connected with dykes of diabase, and of a small percentage of nickel $(0.30$ per cent $)$ in one of his specimens of an argillaceous manganese ore, has no direct bearing on the question of origin. Even if the native iron had been found resting upon the said ore deposits instead of several miles away, a genetic relation would still have to be proven, and until direct evidence was presented most petrologists would probably regard the relation as casual rather than genetic.

No specimens of the diabase of the vicinity of Sâo Francisco have come to hand. Assuming that it is of the usual character of the diabases of similar regions in Brazil, it is not so unlike the basalt, or dolerite, of Ovifak that a comparison might not with propriety be made. It neither approaches nor differs from the iron-bearing Greenland rock more than do the normal diabases of other parts of the world, in which as yet nothing analogous with the Ovifak occurrence has been noted. If the diabase or some related highly basic rock had been found in immediate contact with the iron, a comparison with the Ovifak occurrence would be justified. but even then complete proof of a terrestrial origin would be lacking. As the case stands at present, with tolerably satisfactory evidence that the iron rested on highly acid rocks or their debris, the hypothesis of such an origin involves that of the formation of native iron under conditions entirely different from those of Ovifak.

Another argument in favor of the meteoric origin of the iron may be drawn from the state of preservation of the masses. Although the metal itself is more than usually resistant to oxidizing agencies and to the action of acids, the abundant presence of pyrite renders it peculiarly susceptible to alteration. All the smaller masses are completely changed to limonite, pieces of the size of a man's head or larger are in large part altered, but still show remnants of metal badly fragmented and oxidized in the centre, and only the larger masses retain perfectly sound metal and sulphide. Even in the dryer air of museums it is not a good-keping iron, the disintegrating action of the decomposing sulphide being singularly favored by the fragmented condition of the metal. Under these circumstances it is extremely improbable that, buried in the soil and exposed to the extremely rainy climate of the coast region of southern Brazil, the iron could have been preserved for more than a few centuries at the utmost. The hypothesis of a terrestrial origin involves the exposure to destructive agencies through untold geological ages, since the present topographical features of this part of the Brazilian coast are unquestionably extremely old. In view of the Ovifak occurrence, it is possible and even probable that native iron of terrestrial origin simulating meteorites will be found in other parts of the world and perhaps in rocks of different petrographical types. It is not probable, however, that the first discoveries of this character will be made in surface exposures in the extremely humid coast region of southern Brazil, where the country rock is of Archean age, and the eruptives presumably date back to the beginning of the Secondary age, if not earlier.

\section{NEW TREATMENT FOR SNAKE-BITE AND OTHER POISONS.}

by W. H. Wooster, PResident of the ballarat astro-physical. SOCIETY, VICTORIA, AUSTRALIA.

As poisonous snakes are more or less common in many countries, and the circulation of Science is world-wide, and other cases: of poisoning often occur, and as I have been the means of saving a life by a new process, one that can be applied when it is too late for the orthodox method of cutting and sucking, and used by anybody, with materials at one's hand in every house, I have concluded that I should not be doing my duty if I did not make it known. Some time since, when living in the country, one of the nicest little girls of my acquaintance, about four years of age, was brought to me by an elder sister for diagnosis and treatment. She was swelling from head to foot, becoming cold and stiff in the limbs, and losing her power to answer or even understand questions. As I had been the means of effecting several simple cures: in the district, she was sent in the hope that $I$ would be able to tell instinctively what was amiss, and to cure it as if by magic. As the sequel proved, the latter was almost realized, notwithstanding that in regard to the former I was quite at sea. She had never known what a snake was, but for strategic purposes, wellknown to managers of children, had of ten been terrified with the name of "bulldog" without knowing what that was (bulldog was the popular name for a very poisonous, pugnacious, and gigantic ant, Myrmecia vindex); so that whenever she got stung or bitten by anything, it was put to the credit of the bulldogs, as on this occasion. She had screamed and fallen a few yards from the house, and told her mother a bulldog had bitten her on the foot; and that was all she knew. The foot was examined, but from: running barefoot was so full of scratches and punctures that none could be fixed on as certainly the marks of snake-fangs. The mischief had occurred about an hour before I saw her, and while being examined she was getting rapidly worse; the swelling, coldness, and stiffness were becoming alarming, the lips as thick as one's thumb, the hollows on each side of the nose were filled up level, and of a steel-blue and sea-green color, the arms, lower limbs, and body were becoming blotched with irregular raised parts, white and hard, the spaces between being sunk and darkpurple; the pulse, too, was getting exceedingly feeble. Not thinking a bulldog ant could produce such effects, and not being certain that it was a snake-bite, I concluded that it might be a spider-bite, as my only brother had nearly lost his life from that cause. Even if the place of the bite or sting could have been found, it was clearly too late to cut and suck, for the poison was already all over the body, and rapidly mastering the vital functions; besides which, no one in the district had an ammonia syringe for hypodermic injection. The question was, What could be done? Precedent said: Send for a doctor. But there was none nearer than eight miles, and then he might not be at home; or, if at home, most likely intoxicated; and, besides that, she looked as though she would die before a doctor could see her.

In this conflict of thought and feeling, a happy idea struck me. I had proved in my own person the power of a bydropathic, hotsweating-pack to produce a flood of perspiration, and throw off impurities from the blood, and it now occurred to me that if could sweat the poison out from the whole surface, it would not matter where it got in, nor what put it there; and, moreover, that if it were any good, the danger would be over before anyone could get half-way to the doctor's; and, if twenty minutes or so produced no benefit, the doctor could still be sent for as a last resource. It was a great responsibility, but under the circumstances I felt it a duty, and went to work. Of course, there was no hot water ready, but we soon made some, and put it into a tub, into which the child was placed, with a blanket over all, tucked in close round the neck to keep the steam in, but leaving the head out. This was to open the pores of the skin quickly. While in this I spread a piece of oilcloth on the table, and a pair of blankets: on that. As soon as more hot water was ready, a sheet was wrung tightly out of it, and spread on the blankets. The child was laid on this, and then first one side, and then the other lapped over her, and it was tucked in close about the neck; then the 